\title{
The relevance of Kom ethics to African development
}

\author{
Mbih Jerome Tosam
}

Department of Philosophy, Higher Teacher Training College Bambili, University of Bamenda, Cameroon

Email address:

mtosam2002@yahoo.com

To cite this article:

Mbih Jerome Tosam. The Relevance of Kom Ethics to African Development. International Journal of Philosophy.

Vol. 2, No. 3, 2014, pp. 36-47. doi: 10.11648/j.ijp.20140203.12

\begin{abstract}
This paper uses the moral philosophy of the Kom people of the North West Region of Cameroon as a paradigm of an African moral thought. The paper hinges on the premise that contrary to some Western ethnographic categorization of Africans as primitive and bereft of the capacity for ratiocination and morality, the concept of good and evil, right and wrong, and virtue and vice, on which morality is embedded, are cultural universals. Kom ethics is essentially communitarian; it prizes interpersonal relations in an interdependent world. An action is right if it promotes the common good, and is wrong if it does not. In this paper I argue that the surest way to African development lies in a critical synthesis of African traditional and Western ethical values. No society which is said to be developed today has done so by completely jettisoning its own values. Development requires adaptation, borrowing and learning from others, and the filtering of values; it does not require the complete rejection of our cultural beliefs, values and practices. The predominant Western ethical values, utilitarianism and Kantianism, have been deficient in proffering solutions to Africa's development problems. Utilitarianism and Kantianism emphasize respect for individual autonomy, thereby distancing persons from others, and discouraging solidarity with other members of the community. The West has a lot to learn from African indigenous cultures, if she can be open and tolerant as other cultures have been to Western culture because every culture is a borrower and lender.
\end{abstract}

Keywords: Kom, African Ethics, Morality, Solidarity, Common Good, Values, Development

\section{Introduction}

One of the consequences of the African encounter with the West was the misrepresentation and suppression of African thought and culture. Backed by the racist theories of some prominent modern thinkers like Hume, Kant, and Hegel, and amplified by agents of colonialism like explorers, missionaries, and anthropologists, the colonialists disrupted and distorted African traditional cultures and imposed Western categories of thought. The African was presented as primitive, and bereft of the capacity for rational (and moral) thinking. For example, in the introduction to his Philosophy of History, Hegel writes: "Among the Negroes moral sentiments are quite weak, or more strictly speaking, non-existent. Parents sell their children, and conversely children their parents, as either has the opportunity" [1]. The result of such misrepresentation and superimposition is that, "until now, Western interpreters as well as African analysts have been using categories and conceptual systems which depend on a Western epistemological order" [2] Mundimbe (1988). For such analysts, it would be absurd to talk about
Kom/African ethics. The debasement of African moral values was further heightened by followers of Darwin's theory of evolution by which African traditional values were studied from a comparative standpoint "with the aim of measuring the pace of evolution in relation to Western societies. African ethics served as evidence of the savage in the early human condition before the advent of civilization and modernity" [3] Murove (2009).

However, although European colonization largely disrupted African indigenous cultures, and promoted Western epistemological and moral worldviews at the detriment of African episteme, it is not the case that some aspects did not remain unscathed. As James K. Kigongo rightly observes, although "European cultural and intellectual colonization is a historical reality for Africa, it did not completely erode the sense of Africanity that was, in fact, the fundamental motivating factor of the independence struggle" [4] Kigongo (2002). Contrary to most Western theorizing about Africa, it has been shown, from the avalanche of recent academic works on African thought, that rationality is not the preserve of any particular race or culture, but a universal human feature which may 
be possessed in varying degrees [5] Hallen (2009).

This paper uses the moral system of the Kom people of the North West Region of Cameroon as a paradigm of an African moral thought. To say that Kom ethics is African does not mean that all sub-Saharan African cultures share the same moral values and beliefs as if the continent was a harmonious whole culturally speaking. It only means that such values and beliefs are shared by most sub-Saharan cultures.

The paper centres on the premise that contrary to some Western philosophical and anthropological categorization of Africans as primitive and lack the capacity for rationality, the concept of good and evil, right and wrong, and virtue and vice, on which morality is rooted, are cultural universals. The survival of any society depends on such guiding moral values and ideals. It is from this perspective that Kwasi Wiredu proffers: "Morality in the strictest sense is universal to human culture. Indeed, it is essential to all human cultures. Any society without a modicum of morality must collapse" [6] Wiredu (1998). In order to ensure peace and harmony, every human society lays down standards to guide and regulate behaviour for the common good and progress of that society. These values and ideals are usually deeply-rooted in the beliefs, customs, practices and institutions of all societies. Using Kom proverbs and views from other sub-Saharan African cultures, I show that African culture is rich in moral values that can serve as a springboard for African development.

The paper is divided into two main sections. Section one focuses on morality in Kom culture. It examines some of the concepts commonly used in the Kom language to designate ethics, to commend good/right and/or to castigate bad/wrong behavior. It also discusses the importance of (good) character in Kom ethics and examines three cardinal and intimately related values - solidarity, humanity, and community, in Kom ethics. Finally, section two discusses the relevance of traditional Kom/African ethics to the quest for development in Africa.

\section{Why other Moral Worldviews are Necessary in the World Today}

In an era of globalization where there are conflicting cultural worldviews, and where the Northern mainstream values have proven inadequate in responding to global moral crisis, there is the need to explore non-Western worldviews of the good to complement the deficiencies of Euro-American moral values. Moreover, one of the reasons for the failure of Western ethics, especially in Africa, is because its application does not take African and non-Western values into account. As Africans are frantically searching for development, there is an urgent need for an appraisal of some traditional values. This paper provides suggestions from Kom culture to this task. The rationale is that some moral insights from Kom/African moral thought may be crucial in making up for the moral void in post-independent Africa and may also help to proffer solutions to similar moral challenges in other parts of the World. In the quest for development in Africa, it may be unwise to unthinkingly copy Western values with all its limitations; there is need to reclaim African traditional values some of which were displaced as a result of the colonial encounter. Furthermore, as M.F. Murove contends:

In a world that has become interconnected, where one is continuously meeting people from different cultural and religious backgrounds, the need to know and understand other ethical traditions is an inescapable reality. It becomes imperative, therefore, that any genuine study or teaching of ethics must be comparative and applied in perspective. An ethics course that only teaches Western philosophical ethics (deontological ethics, utilitarianism and virtue ethics) is quite deficient, as becomes glaringly apparent when considering the plurality of existence in the modern globalised world. [7] Murove (2009).

From this perspective, therefore, to give a blind eye to other ethical traditions is to do injustice to humanity because as there is no perfect human culture, we may learn from the strengths and weaknesses of each culture. Again, "a study of comparative ethics is an adventure into freedom. It is freedom to dare to know and appreciate other people's lives without trying to change" [8] (Ibid.) or impose our worldviews on them, or make their lives look like ours as the colonialists tried to do. Therefore, "there can be no genuinely global ethic until non-Africans start taking the rich and immensely long-standing ethical heritage of black Africa seriously" [9] Prozesky (2009).

\section{Morality in African Culture: Human Conduct as a Fundamental Component}

The terms ethics and morality are commonly used interchangeably to mean rules, principles, and standards of right and wrong, good and evil in human conduct [10] Audi (1999). In itayikom, the language spoken by the Kom people, the term which denotes ethics or morality is the expression nchini Kom, which may be literally translated as Kom character/ethics or Kom culture. The Kom expression

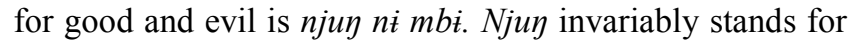
good, right, happiness, joy, pleasure, and beauty, while $m b \dot{t}$ denotes something bad, wrong, evil, painful, ugly, disgusting and distasteful. In Kom moral philosophy, human conduct is a fundamental determinant of a human being. For instance, to say that an individual has a good character or s/he is morally upright, it is almost always said: Wa kel nchini ijuy, which, literally, means "you have morals, you have a good character, or you are a good person"; and by contrast, to say that a person does not have a good character, or s/he is not a good person, it is said: wa kel wi nchini, which means "you don't have morals/character", or "you are not a (good) person." From this, it may be correct to translate the expression nchini 
Kom as Kom ethics, because the expression Kom character, which the expression nchini Kom translates into, does not make as much sense as the term Kom ethics.

It is important to note that the use of the word character to denote ethics, morality or culture is not peculiar to the Kom and/or African cultures; the Greek word ethos, from which the word 'ethics' has its origin means 'character' [11].

In the Kom language, the moral character of a person, albeit suggesting the behaviour of the individual, is also used to refer to a good person, wul. For example, when a person says wa ghi wul (you are a person), s/he, literally, means you are a good person (you are a morally upright person), or you have a good character. Hence, morality in Kom thought is inextricably linked with the normative person. When it is said: wa ghi wi wul (you are not a person) it simply means your behaviour has fallen short of the standard of being human. Good conduct forms the nucleus of Kom ethics. A person's character is determined by his/her actions.

In most Bantu African cultures, the word character is commonly used as the equivalent of ethics such that "discourses or statements about morality turn to be discourses or statements essentially about character" [12] Gyekye (2010). There are other examples across sub-Saharan Africa: For the Nso', also of the North West Region of Cameroon, a person "is conduct" or character, wir dze lii [13] Mofor (2008). A good person (wir wo jún) is one who loves, cherishes and promotes "truth, peace, uprightness, compassion, 'well-being' (dze ye júni) and other similar moral qualities and enduring cultural values" [13] (Ibid.). By contrast, the expression lii wo bi (bad conduct) denotes a "dishonorable or contemptible character, a "worthless personality" [15] (Ibid.). In the Akan language, to say that one has no morals or his/her behaviour is unethical, it is said: Onni suban, "s/he has no character" [16] Gyekye (2010). In the Yoruba language, the word for a morally acceptable behaviour is differently called iwa rere, iwa irele, iwa tutu, or iwa omoluwabi [17] Bewaji (2004). These are also used to mean both character and morality. "In Shona, the language spoken by a predominant majority of the people of Zimbabwe, the word tsika means 'ethics' or 'morality'. But when one wants to say of a person that "He has no morals", or "He is unethical", they would often use the word hunhu which directly means 'character'. Hence, Haana hunhu means "He has no character", "He is not moral" [18] Gyelye (2010).

In Kom moral thinking, the word person $(w u l)$ is used normatively and descriptively. Normatively, it is used to distinguish a good from a bad person. For instance, to praise someone for a good behaviour, the Kom person would say wa ghi wul (you are a person), or wa kel nchini (you have morals), as opposed to wa ghi wi wul or wa ghi nyam (you are not a person or you are a beast) [19] Tosam (2012). And, descriptively, the term wul is used to distinguish a human being (biologically) from other creatures. From a normative standpoint, therefore, the distinction does not suggest that some people are human, in the biological, descriptive, sense, and others are not, but, simply, that some people have a good character and others do not. What this means, also, is that an individual can be human, but not a moral/real person (nkainti wul) in the normative sense. In Kom moral thought, being human, is not morally special, but being a good person is. This distinction also means that a real human being is a being with a moral conscience. From this outlook, what is important in the determination of the character of an individual is action, the way in which a person's behaviour, positively or negatively, affects others. In morality, his/her deeds, and not his being, are the most important. Talking about the fundamental place of human conduct in African ethics, Mbiti writes:

The essence of African morality is that it is more 'societary' than 'spiritual'; it is a morality of 'conduct' rather than a morality of 'being' for it defines what a person does rather than what he is. Conversely, a person is what he is because of what he does, rather than that he does what he does because of what he is [20].

From this, therefore, it follows that what a person is, is less important than what $\mathrm{s} /$ he does. It is through actions that we can judge whether an individual is a good or a bad person.

The primary role of the family and the community in the African moral universe is to inculcate positive attitudes, moral norms, ideals and virtues such as honesty, kindness, compassion, respect for others, and a sense of the common good. Hence, the conduct of a person is a reflection of the kind of (moral) education s/he has received from his/her community. If the individual has a bad character, then his/her community failed in their function of moral education and character building. This does not suggest, however, that the individual is not free to choose whether or not to respect the norms of good behaviour, but that the person who finds these principles and rules worthy of respect and actually puts them into practice in his/her daily actions, is a good person. From this perspective, it implies that a human being is "originally morally neutral" [21] Gyekye (2010), s/he is neither good nor bad from birth, but learns about right and wrong, develops a moral sense, as $\mathrm{s} /$ he grows and interacts with members of his/her community.

\subsection{Some Cardinal Values in Kom Moral Philosophy}

There are three fundamental and closely related values in Kom moral thought: solidarity, humanity, and community. There may, nevertheless, be other important ideals, but the three are the most palpable defining values in Kom traditional ethics.

\subsection{Solidarity and the Common Good}

Kom ethics has been described as essentially communitarian [22] Tosam (2012). Communitarian ethics places a special premium on the moral superiority of the 
community over the individual. Here, life is considered as a shared property and not the exclusive dominion of the individual. According to this ethical view, an action is right if it promotes the common good, and is bad if it does not. In the Kom society, there is a deep sense of common concern and understanding between members of the community. There is concern for each other's problem(s). The following Kom proverb highlights the importance of solidarity and interdependence in Kom culture: Ninyiy nin joft kisì àvinà. This may be literally translated as self-alienation/aloofness is good only for a witch/wizard. What this proverb invokes is the idea that a human being, qua human being, is an interdependent being, and cannot survive alone without co-operating and sharing with other members of the community. If s/he does not interact, share, assist and accept assistance from others, then his/her behaviour falls below the standard of being human. This equally means that it is only in the community that a person can attain genuine personhood. In the same communalistic standpoint, another Kom proverb states: awu àmi'a ka'ki bû loe kul ibu', which means one hand cannot tie a bundle. This means that human beings are not self-sufficient and cannot achieve anything great without assistance. To accentuate the significance of human interdependence in Kom society, another proverb states: ingomi bu timi toh bula intom. Plainly, this means 'banana never gets mature without a supporting stick.' Hence, we cannot succeed in life, without the aid of others.

In the Kom community, those who do not identify and empathize with others are treated according to their behaviour. They are left to themselves when they are in difficulties. This is usually used as a corrective measure to make such egocentric individuals understand that they cannot live as an island. But if their self-regarding behaviour continues, it could result in their complete social exclusion. Life is all about sharing. If you do not share with others, do not expect to receive from them. If you do not contribute to the well-being of others, do not expect support when it is your turn. The Kom idea of giving and taking is in accordance with the biblical teaching that the more you give, the more you receive [23] Proverbs. The Kom believe that the gods provide abundantly for those who are generous [24] (Ibid.).

\subsection{Humanity}

Human well-being is at the foundation of all moral traditions. Everywhere in the world ethics is aimed at the promotion of human well-being, peace and harmony and to prevent the disintegration of the society. In Kom ethics, the human person is special and his/her wellbeing is "above all price", to borrow the Kantian expression. The following Kom proverb invokes this special place human beings occupy in Kom ethics: Nchi wul misong nin chwo nchi nyàmsi. Literally, this means 'watching over human beings is more important or demanding than taking care of animals.' What this proverb highlights is the idea that because human beings are morally special (they may be harmed physically or psychologically), they need to be treated with dignity. This is the humanist dimension of Kom/African moral philosophy. Commenting on the fundamentally humanist character of African ethics, K. Wiredu writes: "It has often been said that our traditional outlook was intensely humanistic. It seems to me that, as far as the basis of the traditional ethic is concerned, this claim is abundantly justified" [25] In Kom moral thought, what is right is what brings people together; what brings discord is wrong. It is for this reason that the moral character of a person is of paramount importance in society. In the same light, another Kom proverb says: gyà ijuך nìn chwô àfo, translated as 'kind/loving words are better than a gift.' Peace and harmony are some of the values highly prized in Kom ethics. A peace-loving, honest, generous, hospitable, and compassionate person is a real person in the moral/social sense. Such persons are usually rewarded by the community in diverse ways for their good conduct. A person whose language and deeds are cruel, and who provokes avoidable conflict, brings dishonour and ill luck to himself and to his/her entire community. Such people are usually reproached, chastised, or corrected; but not socially excluded, although they may sometimes be excluded if their repulsive and inconsiderate behaviour becomes unbearable. The following proverb underscores this idea: ghi lum mà'ì ki iwo, ghì bû timi ima'ì wul, which means 'we only dispose of what (the spiteful words/behaviour of a person) a person says and not the person who says them.' For the Kom, therefore, you only have to "hate the sin but not the sinner" [26] Hamilton (2009). When we hate the sin and the sinner, we may be tempted to get rid of both. Because the object of Kom morality is human welfare, we need to forgive and correct a bad behaviour and not get rid of the bad person. Stating the importance of human welfare in African moral thought Wiredu once more posits: anyone who reflects on our traditional ways of speaking about morality is bound to be struck by the preoccupation with human welfare: what is morally good is what befits a human being; it is what is decent for man-what brings dignity, respect, contentment, prosperity, joy, to man and his community. And what is morally bad is what brings misery, misfortune, and disgrace [27].

In Kom culture, good and fruitful relationship is highly valued so that when one ruins a good relation, one is, metaphorically, said to have defecated on his/her path: Wà gin a wiu ibyes, 'you have destroyed a good relationship.' This proverb invokes the importance of brotherhood, decency, trustworthiness, and the special place human relation occupies in Kom social thinking.

\subsection{Community}

The community is the setting per excellence where ethics and an ethical life can be observed and/or practiced. No one can be judged good or bad if $\mathrm{s} /$ he lives in isolation. We are born into a particular society and immersed into a particular culture, willy-nilly. As a member of a given society, we have an obligation to contribute to the well-being of that 
society. Hence, according to African moral theory, an act is right if it conforms to the values and rational principles laid down by the community, and is wrong/bad if it does not. Individual persons are seen as the property of their communities not in the sense that they are submerged in their community or that their rights are restrained; but that they are simply considered communal persons who cannot be complete in isolation because our humanity is a shared one. I do not assist others in difficulties because I think they have a right to be assisted, but because it is my duty to help any fellow human being in distress. This is what any other person is expected to do, and must do, if s/he is to be considered human, to any other member of the community found in a similar situation.

According to the Kom conception of a person, life is not the possession of the person who lives it; it is also a gift for which we are merely guardians with certain responsibilities [28] Tosam (2012). For instance, a child is said to belong to one person only when $\mathrm{s} /$ he is still in the womb; when the child is born, s/he becomes the 'property' of the community Since the full realization of personhood is in the community, this means that the criterion for judging an individual as a person is based on how well s/he cares for, and shares with those with whom he entertains a mutual relationship.

The common good forms the basis of communitarian ethics. K. Gyekye fittingly puts this when he says:

Communitarianism immediately sees the human person as an inherently...communal being, embedded in a context of social relationships and interdependence, and never as an isolated, atomic individual. Consequently it sees the community not as a mere association of individual persons whose interests and ends are contingently congruent, but as a group of persons linked by interpersonal bonds, biological and/or non-biological, who consider themselves primarily as members of the group and who have common interests, goals and values. The notion of common interests and values is crucial to an adequate conception of community; that notion in fact defines the community. It is the notion of common interests, goals, and values that differentiates a community from a mere association of individual persons [29].

What this implies is that in the African worldview, the good of the community is central and takes precedence over the good of the individual. As an isolated person, seeking only his/her own interest, the individual is incomplete.

Mbiti provides an apt illustration of this communalistic view of persons in African ethics: "A person is a person through other persons....The individual can only say: I am, because we are; and since we are, therefore I am" [30] Mbiti (1969). The Kom put this idea of the necessary interdependence of persons in the community in the way as follows: wul nin ghi wul bôm wul, which means "a person is a person through/because of other persons." In Kom social thought, the individual is considered as incomplete and self-insufficient and social interaction is meant to complement this inherent human self-insufficiency. To succeed in whatever endeavour, we need to support, and be supported by, others. On our own we cannot achieve anything great. For the Nso', the phrase wir dze wir bi' wir, man is man by other men", means "the individual's adherence to the value-systems derived from, and wedded with the world of the Nso' cannot be considered independently of the community... in which they live. Here, there cannot be any contradictions between the fundamental existential concerns of the individual and the existential concerns of the community... [31] Mofor (2008).

It is in this important sense that the character of the individual "not only depends on, but also determines and gives meaning to the conduct of the community" [32] (Ibid.). The achievements and/or failures of a member of the community are considered as the achievements or failures of the community as a whole.

Moreover, the expression wul nin ghi wul bôm wul speaks of the reciprocal responsibility of the individual and the rest of the community, which derives from the strong bond of brotherhood or solidarity that is essential for community survival. In traditional African society, those who were more gifted, say, in knowledge, skill, power, or wealth, had the moral obligation to help, or share with those who were not, since their talent was considered as a gift from God and any selfish and self-regarding use of such talents could provoke the wrath of the gods and cause them to strip off their gift. For example, traditional healers, artists, sages and others offered their services and knowledge free of charge because they considered them as gifts from God.

\section{The Relevance of Kom/African Ethics to Development in Africa}

Kom moral thought, like any other indigenous African philosophy, which has suffered from the negative effects of colonialism, neo-colonialism and globalization, is under threat of annihilation. From the foregoing analysis, the following questions arise: If Kom/African morality is essentially humanistic and community centred, why are there still so many cases of immorality, individualism and antihuman behaviour such as the inhuman treatment of others, egocentrism, avariciousness, dishonesty, hatred, debauchery, the degrading of human life, and above all, the abuse of power, in Africa today? In fact, the contemporary African lives in complete reversal of values. What are the reasons for this transposal of values? Can these traditional moral values help in the search for sustainable development and a better society in Africa today? Would it not be anachronistic or waste of time to try to revive traditional values in our contemporary multicultural and sophisticated society, which have completely new realities and challenges from traditional African societies?

These were some of the questions which preoccupied most post-independence African philosophers/politicians. 
To respond to them, they were, and still exist, two contending camps. The first camp is made up of those who looked back to African traditional culture with reverence and nostalgia and called for the revival of suppressed and neglected values as the surest way to African development. This camp is represented by intellectuals and post-independence leaders like Senghor and Nyerere. 'Revivalists' [33] Ciaffa (2008), as they are sometimes called, see development from a Western model, as some sort of perpetuation of Western colonialism. The second camp is made up of those who are of the opinion that the only way to development in Africa is through the appropriation of Western science and technology. This group is represented by African philosophers like Paulin Hountondji and Marcien Towa. According to them, returning to the past would be anachronistic because indigenous traditions do not only impede progress, but "divert attention from pressing political issues, such as authoritarian oppression and class exploitation, and endorse forms of thought that interfere with the important goals of scientific and technological advancement" [34] (Ibid.). These thinkers call for a complete departure from the past. Towa, for example, maintains: "...it is only with the means furnished by the present that we can revolutionize the present" [35] (1979). For this reason, Towa maintains that to affirm ourselves on the world stage as completely liberated persons, we must deny our essence and our past, we must strive to become like the other-the West, and therefore become uncolonisable by the other. We must destroy traditional idols [36] (Ibid.). For him, our past is responsible for our current state of stagnation and subjugation, so, we must negate it. Between these contending camps, was Kwame Nkrumah who thought that it was necessary to be cautious about thoughtlessly appropriating Western values.

There are a number of conflicting cultural influences in Africa today which are said to be responsible for the decline of indigenous values, namely, European colonialism, Christianity, Islam, Western secularism and globalization. These clusters of competing influences have left the African more confused and almost completely extricated from his/her traditional past. As Wiredu aptly puts it:

Contemporary African experience is marked by a certain intellectual anomaly. The African today, as a rule, lives in a cultural flux characterized by a confused interplay between an indigenous cultural heritage and foreign cultural legacy of a colonial origin. Implicated at the deepest reaches of this cultural amalgam is the superimposition of Western conceptions of the good upon African thought and conduct. [37] Wiredu (1996).

However, in spite of the changes that came with these competing influences on African culture, African culture was not completely eroded; rather, these values only "lost their intrinsic importance in the people's thinking and assumed a peripheral role in the event of colonization and its attendant cultural impingement" [38] Kigongo (2002).
Any sustainable development in Africa would require a critical analysis, a sifting process, and not an uncritical negation of the past. It will require scrutinizing and appropriating those positive values in African and non-African cultures that may be beneficial for African development and discarding those values, from both African and non-African cultures that are inimical to human development.

\section{How African Traditional Moral Values can contribute to African Development}

The moral values of a people determine their economic and political behaviour. It is in this sense that the moral beliefs and values of a society cannot be completely detached from their political and economic attitudes and performance [39] Johnson (2013). It is also for this reason that my analysis, from time to time, has touched, and will still be touching, in what follows, on some economic and political issues that seem to depart from the main thrust of this paper.

African ethics is holistic and has respect for all living things on earth-plants, animals, humans and the living-dead. It cherishes a philosophy of live and let live, be and let be. This ethical and metaphysical worldview has been described as "eco-bio-communitarian" [40] Tangwa (2000) According to this view, human beings, that is self-conscious and self-determined persons are not special and do not have the right to dominate and control the rest of nature, as it is the case in Western ethics; they are simply, because of their rational nature, liable and therefore have the responsibility to take care of, and protect the non-rational (or those yet-to-be) agents of nature. What this implies is that in the hierarchy of existence in the African universe, moral obligations are ascribed only to humans, out of all the creatures with which they share the cosmos. It is a moral worldview that "goes beyond anthropological communality" and even beyond "bio-communitarianism" [41] Tangwa (1996) because there is a close relation between the natural and supernatural. Such relation has, prompted an attitude "towards nature and all living things that is cautious, reverentially respectful, and almost ritualistic. It brings about a deep-seated attitude of live and let live, be and let be, which finds practices as the system of consensus for resolving interpersonal and intercommunity disagreements and differences" [42] (Ibid). In the African worldview, there is tolerance and acceptance of others, there is no discrimination based on species or on physical or mental ability. This traditional African moral outlook is relevant today especially at a time when global warming and climate change is causing havoc to the environment, causing health, social and economic challenges such as floods, droughts, poverty, impoverishing the world in terms of biodiversity, medicinal plants.

In the same light, and in connection with traditional 
African attitude towards disease,

The morality of an action or procedure is to be determined from the standpoint of the agent rather than that of the patient .... In other words, a moral agent can do moral good or evil, irrespective of whether the patient of his or her action...is a person, nonhuman animal, a plant, or even an animate thing. What the attributes of self-consciousness, rationality, and freedom of choice do, as well as those of power and wealth, is load the heavy burden of moral liability, culpability, and responsibility on the shoulders of their possessor [43] Tangwa (2000).

The idea here is that as members of a community, our actions always affect others, positively or negatively, and our humanity is determined by the impact of our conduct on others. As rational beings, therefore, we have a moral obligation to protect the rest of nature.

In African traditional society, and as far as hunger and disease were concerned, commerce and profit were usually ignored for the good of the human person. Here human relation was considered to be the most important. It is for this reason that medicine was completely detached from commerce. In the case of an outbreak of epidemic, for example, traditional healers mobilized their know-how and services free of charge for the common course. This practice stems from the African belief that medicine has nothing to do with commerce because it is concerned with human subsistence which is above any price. Any healer who charged a fee for his/her services was considered an impostor. Hence, in the traditional African society, those who had expert knowledge did not earn a living from their art because it was considered a God-given talent that must also be dispensed of free of charge for fear of being stripped of such natural gifts. Tangwa highlights this idea when he says: "Medical practitioners, carvers, entertainers and other artists... never charged any fee for their professional services, for fear of losing their specialised skills and natural endowments" [44] Tangwa (1999). This moral attitude towards disease and commerce contrasts with the "Western economic idea and practice, more or less successfully globalized, whereby the more desperately you need a product or a service, the more you are required to pay for it under the so-called law of supply and demand" [45] Tangwa (2002). The quest for profit at all costs, even at the expense of human life, the desire to patent (which is not without corruptive influences), to measure and calculate even the immeasurable and incalculable aspects of human life like happiness, are some of the weaknesses of Western culture that Africans should be cautious about their quest for development.

Through Western education, Christianity, and Islam, the colonialists disrupted the community-based way of life that Africans lived by and introduced an individualistic ethos where individuals see themselves as self-seeking and self-governing persons detached from their communities. The consequence of this is that it has engendered a materialistic culture where people worship material things, and exploit others as a means of enrichment.
This analysis may give the impression that African culture is perfect as far as moral values are concerned and that other cultures, especially the Western culture, are by essence morally deficient. By emphasizing on the primacy of the community over the individual, and interdependence of members of the community on each other, African culture encourages laziness, complacency, and overdependence. My emphasis on African indigenous values is a call for these values to "function as a source from which to extract elements that will help in the construction of an authentic and emancipative epistemological paradigm relevant to the conditions in Africa at this historical moment" [46] Mogobe (2009).

Globalisation has rather exacerbated the domination of non-Western cultures and facilitated the westernization of the world rather than opened borders, cultures, and economies of the world into a global village where all villagers enjoy equal rights and respect in the exchange of goods and services, and cultural values, as it was highly expected. In the global space, and by virtue of her techno-scientific, economic, political and military might, Western culture enjoys a certain unparalleled dominion over other cultures. For this reason, Africans, especially the younger generations, willy-nilly, influenced by Western values and ideals (and because of the evangelic and crusading force with which these values are propagated) erroneously consider them not only as modern, but also as the best. For this reason, African indigenous values have been relegated to the background. Western education provoked a cultural change in that it encouraged alienation from traditional African values. In the colonial era, and even after independence, those who adhered to traditional African ways of life were considered as inferior and unsophisticated. Modernity for such persons means a departure from traditional values and the assimilation of Western cultural standards and attitudes. Take the case of Western democracy which is considered by some as the panacea to political stability and economic development in Africa. Democracy has rather brought division, hatred, greed, wild materialism, and egoistic individualism in multi-ethic societies. "With the tendency towards individualism, a person's sense of moral value tends to incline more to what benefits him, his family or his ethnic group, which entails a narrow or restricted sense of moral value" [47] Kigongo (2002).

\section{The Eurocentric Conception of Human Nature and its Implication to African Development}

The differences in values between Western and non-Western cultures may also be explained from the differences in the conception of human nature. According to the Western conception, human beings are naturally distrustful of one another. In his The Western Illusion of Human Nature, Marshall Sahlins contends that the Western 
conception of human nature is "so avaricious and contentious that, unless it is somehow governed, it will reduce society to anarchy" [48] Sahlins (2008). Throughout the history of Western philosophy, human beings are portrayed as egoistic, nasty and brutish. From ancient Greece beginning with Thucydides, through St. Augustine, Machiavelli, Hobbes [49] (Ibid.), to the contemporary era, this idea of human nature reverberates. For example, for Hobbes and many other Western thinkers before and after him, the reason why we want to move from the inhuman state of nature to a civil society is to have peace (to avoid anarchy). According to Sahlins, this Western conception of human nature bears the germs of its self-destruction. Because of the sway of Western culture, this view of human nature has become the most predominant in the world today. Thanks to this influence, the West has celebrated her "ethnocentrism by taking" some of her "customary practices as proof of their universal theories of human behaviour. In this kind of ethnoscience, l'espèce c'est moi-I am the species" [50] Sahlins (Ibid.). It is this cultural arrogance, the quest for power, to dominate in order not to be dominated, and the inconsiderate quest for profit which prompted the West to colonize other parts of the world under the guise of a 'civilization mission.'

With this moral conception of human nature, individual persons value their own survival and happiness much more than the survival and welfare of others, and act thus. Hence, if a person believes that a certain course of action promotes his/her own safety, s/he is very likely to undertake it, even if it endangers the subsistence or good of others. The society, therefore, is formed to forestall our innate human bestiality. As Sahlins maintains, society since the middles ages, "has regularly been viewed as a necessary and coercive antidote for our inherent egoism" [51] Sahlins (Ibid.).

In African culture, by contrast, society is not formed as a way of restraining human brutishness, but as a way of enhancing our intrinsic human goodness. According to this worldview, as I have argued above, when we seek the common good, we seek our own good, but when we seek our own good we seek our own destruction [52] Gyekye (1998). Here what determines a human being is not merely his/her body, but his/her character, nchini. A person who has a good character, that is, one who is compassionate, kind, generous, hardworking and trustworthy, is a real person, in the moral sense. On the other hand, a person who is cruel, inconsiderate, selfish, and dishonest, is not a human being in this normative sense. In the Kom language such a person is referred to as a nyam fika' (a beast). It is therefore character, and not species membership, which determines ones humanity. The misconception of human nature therefore is based on the erroneous idea that we must have a central authority to control us, for, without this, society degenerates into disorder. The consequence of this Western conception of human nature is that it has promoted mutual distrust, fear and psychological anxiety, especially in the Western world. This egocentrism and the desire to dominate and exploit the 'other', is partly responsible for the gross economic disparity, the destruction of nature and global insecurity today. Such economic disparity is largely responsible for the animosity against the west, especially in poorer and dispossessed societies of the world. It may be argued that terrorism in the world has been caused by this mistaken and reductionist conception of human nature- $\mathrm{a}$ view of human nature which considers difference as antagonistic - if I am not like you in skin color, belief, or wealth, then I am your foe.

From this perspective, therefore, Western ethical values, Kantianism and utilitarianism, which emphasise individualism have not helped in bringing peace and stability in the world. They have rather promoted fear, suspicion, hostility and the polarization of the world. As Prozesky has observed, "unchecked, individualism and personal freedom of action easily degenerates into selfishness, irresponsibility, greed and even cruelty" [53] Prozesky (2009). In spite of unprecedented advancements in science and technology in the last half of the 20th century, especially in the areas of agriculture and medicine, more than $75 \%$ of the world's population in the developing world is still wallowing in abject poverty, and from curable and preventable diseases. Only a small fraction (about 15\%) of the world is enjoying the benefits of these scientific and technological advancements.

The truth, which is often ignored in individualistic cultures, is that in a world that has become so interconnected, our destinies are also inextricably intertwined. Poverty, misery, disease, and environmental destruction in Malawi, Afghanistan, Chile, Nigeria, or Cameroon, affect and threaten peace and security in the USA, Britain or France, because disempowered and impoverished societies are breeding grounds for terrorists and dissatisfied persons. What is required in Africa today is to engage in a critical synthesis of values. Utilitarian and Kantian ethics do not place much value in identifying with others, with the weak and the poor. For example, "a Kantian can respect others by being distanced and not including them in any "we"" [54] Metz (2009), since what is important for him is to respect individual autonomy. African ethics, by requiring persons to strive to improve the well-being of others, cherishes a harmonious relationship, that is, showing solidarity for one another.

\section{A Critical Synthesis of Values as a Way Forward}

In the quest for development in Africa, there is need to engage in a critical but cautious synthesis of values since no human culture is perfect. Each culture, like any human enterprise, has its strengths and weaknesses. For this reason, the quest for development in Africa should not involve the total negation of indigenous values, but in a blend of traditional African values with Western as well as non-Western values. This idea is not new; Nkrumah was the champion of this moderate position. In his Consciencism, 


\section{Nkrumah writes:}

Our history needs to be written as the history of our society, not as the story of European adventures. African society must be treated as enjoying its own integrity; its history must be a mirror of that society, and the European contact must find its place in this history only as an African experience, even if as a crucial one. That is to say, the European contact needs to be assessed and judged from the point of view of the principles animating African society, and from the point of view of the harmony and progress of this society [55] (1969).

This assessment and synthesis of values is necessary because, no part of the world can claim to be developed in the holistic sense. The search for development is an ongoing process in which all societies of the world are involved. We must engage in an intercultural exchange where the strengths and weaknesses of each culture are acknowledged, openly debated and the positive values promoted, and the negative ones abandoned. In this process of intercultural exchange, "other cultures should be able to beg, borrow or buy Western technology without having to take along with all its Western packaging, its entire surrounding value system" [56] Tangwa (1999).

By arguing that we need to recover some traditional values, I am not encouraging a nostalgic eulogization of the past, but calling for a critical examination of the past. No society which is said to be developed today has done so by completely forsaking its culture or by denying its past. "The past can serve as a teacher and even as a midwife of new culture" [57] Ikeke (2013). The concept of development has been mistakenly considered by most development analysts to mean only scientific and technological sophistication. An important component of development usually neglected in the discussion on development is the moral and spiritual dimension. A holistic view of development sees it as moral, spiritual and intellectual, and material improvement. Without moral and spiritual advancement, there may be no material development. Moral, spiritual and intellectual developments are the necessary ingredients for material development everywhere in the world. Development requires adaptation, borrowing and learning from others; it does not mean the abandonment of all our cultural values, institutions, and practices. For example, in their quest for development, Japan and China did not completely reject their cultures. They borrowed and appropriated aspects of foreign cultures, especially Western culture. As Ciafa argues: "Progress in any society requires adapting, changing, and in some cases abandoning traditional ideas and behaviour. It also involves borrowing and adapting ideas from other cultural contexts" [58] Ciafa (2008).

In the situation of conflict between indigenous African and foreign values, critical revivalism may be the rational solution. By critical revivalism, I mean a rational and cautious appraisal of African and non-African values with a view of eliminating those aspects in both cultures that are antithetical to human flourishing and upholding only those which promote human welfare. In other words, in order for us to make any meaningful strides towards progress in Africa, we need to take a leap backwards while also paying attention to our present conditions and realities. As C. Okoro rightly puts it:

The truth is that any people who have lost touch with their past would definitely find it difficult to develop as societal cohesion becomes manifest only when development strategies are married upon native myths and principles. Besides, these native myths and principles help in the re-adaptation or Indigenization of alien ideologies [59] Okoro.

Development in Africa neither depends on re-living the past nor in the credulous appropriation or domestication of Western science and technology, as Hountondji and Towa argue, but in a combination of both-in a blend of the positive values of science and technology (objectivity, self-criticism) with the humanistic ethos of Africa. It would be for the good of humanity if all cultures are allowed to flourish since no human culture is perfect. "It would profit us little to gain all the technology in the world and lose the humanistic essence of our culture" [60] Wiredu, (1980). It is by critically examining our culture and borrowing from others that we may achieve sustainable development in Africa. "The way to progress is openness to new ideas. A culture that is not open to ideas (be these ideas indigenous or foreign) soon stagnates and atrophies" [61] Wiredu (Ibid.). It was not everything in traditional African society that was good. We need to engage in a careful sifting of values and encourage only those values which promote love, peace, honesty, compassion, hard work and the common good. The problem with corporate living is that it de-emphasizes individual autonomy, critical thinking and creativity and sometimes breeds laziness, lack of individual initiative and overdependence of members of the community on hardworking and ingenious individuals which may lead to intellectual and economic stagnation.

The weakness of Western techno-science is its capitalist and anti-humanistic character. To argue that development must involve a complete break with the past as modernists claim, gives the impression that there are some cultures (like Western culture), which are perfect, and what other societies need do is to uncritically appropriate, if we want to progress, for it is 'the way, the truth and the light.' This, in my opinion, is legitimizing the so-called "civilizing mission" of the West, which, without doubt, was a mission to dominate, exploit, and destroy non-Western cultural values. As Sandra Harding proffers, "...the history of the West's systematic destruction of other cultures knowledge systems, coupled with the often brutal material conditions of imperialism and colonialism that made possible the advance of European science, set the achievements of European sciences in quite a different moral and political light" [62] Harding (2001). The Western world is not developed in the true sense of the term; it is only partially developed. Wiredu argues that:

The Western world is 'developed', but relatively. 
Technological sophistication is only an aspect, and that is not the core, of development. The conquest of the religious, moral and political sphere by the spirit of rational inquiry remains... a thing of the future even in the West. From this point of view, the West may be said to be still underdeveloped. The quest for development, then should be viewed as a continuing world-historical process in which all peoples, Western and non-western alike, are engaged [63] Wiredu (1980).

For Wiredu, there are two key benefits in looking at development from this perspective.

The first is that it becomes possible to see the movement towards modernization in Africa not as essentially a process in which Africans are unthinkingly jettisoning their own heritage of thought in the pursuit of the Western ways of life, but rather as one in which Africans in common with all other peoples seek to attain a specifically human destinya thought that must assuage the qualms of those thoughtful Africans who see modernization as a foreign invasion..." [64] Wiredu (Ibid.).

The second advantage is that "....To develop in any serious sense, we in Africa must break with our old uncritical habits of thought; that is to say, we must advance past the stage of traditional thinking [65] Wiredu (Ibid.).

Development in Africa as elsewhere in the world, should take this human and holistic dimension into consideration lest it would be partial and incomplete development. In support of the above view, another Ghanaian philosopher, Kwame Gykye, writes:

I support the view that the humanist essence of African culture...ought to be maintained and cherished in the attempt to create a postcolonial modernity. It must be realized that technology alone cannot solve... deep-rooted problems such as poverty, exploitation, economic inequalities and oppression in human societies unless it is underpinned and guided by some basic moral values; in the absence of the strict application of such values, technology can in fact create other problems, including environmental problems. Social transformation, which is an outstanding goal of the comprehensive use of technology, cannot be achieved unless technology moves under the aegis of basic human values [66] Gyekye (1997).

All this requires that we re-examine our culture and look for a more objective and impartial assessment of its strengths and weaknesses "than the exceptionalist and triumphalist" [67] Harding (2001) Western accounts could offer. The material aspect of development is usually considered as the most important part of development, but this is erroneous because material development is only a part, and not the most important. Human development, and by this I mean moral, spiritual and intellectual development, is a critical aspect without material development is unsustainable and fragile.

\section{Conclusion}

It is evident from this analysis that the concept of morality is universal. It is deeply-rooted in non-Western cultures like African cultures. Moreover, African ethics seems to be more profoundly humanistic than Western moral thought. African proverbs, riddles, idioms, and myths are rich in moral teachings. Kom morality, for example, puts human and community interest foremost. A good act is that which promotes human well-being, and any act that does not promote the good of the community, is bad. A good person is an honest, generous, compassionate, and peace-loving person. An individual becomes a person, moral not biological, only by identifying and cooperating with others. Moreover, human beings do not consider themselves as superior and therefore do not have the mandate to control the rest of nature. They are simply co-occupants (with animals and plants) of nature and have a higher burden, by virtue of their rationality, of responsibility to protect and preserve the rest of nature. It is a culture of live and let live, and be and let be. To considerably reduce poverty, disease, insecurity, and ensure sustainable development in Africa, there is the need to blend both the individualistic impulses of the West with the communitarian sensibilities in some kind of an intercultural dialogue where each party critically examine their culture, acknowledging their strengths and weaknesses and humbly learning from each other. Development does not only involve "technological sophistication," it is also involves moral, spiritual and intellectual advancement. From an African perspective, it is when we are able to share with and show compassion for one another, no matter how different, culturally, racially, and economically, they may be from us.

\section{References}

[1] F.W. Hegel, The Philosophy of History, Translated by J. Sibree, Ontario, Batoche Books, 2001, p.114 (available at socserv.mcmaster.ca/econ/ugcm/3113/hegel/history, accessed $03 / 11 / 2013$ )

[2] Valentine Y. Mundimbe, Gnosis, Philosophy and the Order of Knowledge, Bloomington, Indiana University Press, 1988, p.x.

[3] Munyaradzi Felix Murove, "Beyond the Savage Evidence Ethic: A Vindication of African Ethics" in M. Felix Murove (ed.), African Ethics: An Anthology of Comparative and Applied Ethics, Scottsville, University of Kwa-Zulu-Natal Press, 2009, pp.14-32.

[4] James K. Kigongo "The relevance of African Ethics to Contemporary African Society" in A. T. Dalfovo (ed.), Ethics, Human Rights, and Development in Africa: Ugandan Philosophical Studies, Washington DC, Cultural Heritage and Contemporary Change, Series II, Volume 8, pp. 51-67.

[5] Barry Hallen, A Short History of African Philosophy, $2^{\text {nd }}$ ed., Bloomington: Indiana University Press, 2009, p. 49; see also Kame Gyekye, 1995, An Essay on African Philosophical Thought: The Akan Conceptual Scheme, Cambridge, Cambridge University Press, 1995. 
[6] Kwasi. Wiredu, "The Moral Foundation of an African Culture" in P.H. Coetzee and A. P. J. Roux (eds.), Philosophy from Africa: A Text with Readings, Johannesburg, International Thompson Publishing, 1998, pp. 306-316.

[7] Munyaradzi Felix Murove, "Beyond the Savage Evidence Ethic: A Vindication of African Ethics" in Munyaradzi Felix Murove (ed.), African Ethics: An Anthology of Comparative and Applied Ethics, Scottsville, University of KwaZulu-Natal Press, 2009, pp. 14-32.

[8] Ibid.

[9] Martin H. Prozesky, "Cinderella, Survivor and Saviour: African Ethics and Quest for a Global Ethic" in Munyaradzi Felix Murove (ed.), African Ethics: An Anthology of Comparative and Applied Ethics, Scottsville, University of KwaZulu-Natal Press, 2009, pp.3-13.

[10] [10]Robert Audi (ed.) Cambridge Dictionary of Philosophy, Cambridge, Cambridge University Press, 1999, p. 284.

[11] Mairi Robinson and George Davidson (eds.), Chambers $21^{\text {st }}$ Century Dictionary, Revised Edition, Chambers Harrap Publishers Ltd, Edinburgh, 1999.

[12] Kwame Gyekye, "African Ethics" 2010 http://plato.stanford.edu/entries/african-ethics/\#HumFouAfr Mor (accessed 03/12/2013)

[13] Christian Mofor, Plotinus and African Concepts of Evil: Perspectives in Multicultural Philosophy, Bern, Peter Lang, 2008, p. 208.

[14] Ibid.

[15] Ibid.

[16] Kwame Gyekye, "African Ethics”, op.cit.

[17] Ayotunde I. Bewaji , "Ethics and Morality in Yoruba Culture" in Kwasi Wiredu (ed.) A Companion to African Philosophy, Oxford, Blackwell Publishing Ltd, 2004, pp. 396-403.

[18] Kwame Gyekye, “African Ethics”, op.cit.

[19] Mbih J. Tosam, 2012, "The Kom Conception of a Person", Africa-Dynamics of Social Science Research, Volume 2, Number 2, December 1, 2012.

[20] John S. Mbiti, African Religion and Philosophy, London, Heinemann 1969, p. 209.

[21] Kwame Gyekye, "African Ethics", op.cit.

[22] Mbih J. Tosam, op.cit.

[23] Proverbs 28:27.

[24] Ibid.

[25] Kwasi Wiredu, "The Moral Foundation of African Culture" op.cit., p.6.

[26] Kelly Hamilton, “'Hate the sin but not the sinner': forgiveness and Condemnation" South African Journal of Philosophy, 2009, 28 (2), pp. 114-123.

[27] Kwasi Wiredu, "The Moral Foundation of African Culture" op.cit., p.6.

[28] Mbih J. Tosam, “The Kom Conception of a Person”, op.cit.
[29] Kwame Gyekye, "Person and Community in African Thought" in P.H. Coetzee and A. P. J. Roux (eds.), Philosophy from Africa: A Text with Readings, Johannesburg, International Thompson Publishing, 1998, pp. 317-336.

[30] John S. Mbiti, African Religion and Philosophy, op.cit.

[31] Christian Mofor, Plotinus and African Concepts of Evil: Perspectives in Multicultural Philosophy, op.cit.

[32] Ibid.

[33] J. A. Ciaffa, J. A., "Tradition and Modernity in Postcolonial African Philosophy", Humanitas, Volume XXI, 2008, Number 1 and 2, 121-145.

[34] Ibid.

[35] Marcien Towa, Essai sur la problématique philosophique dans l'Afrique actuelle, 2 me éd., Yaoundé, Edition CLE, 1979, p.40.

[36] Ibid.

[37] Kwasi Wiredu, Cultural Universals and Particulars: An African Perspective, Bloomington, Indiana University Press, 1996, p. 61.

[38] James K. Kigongo, op.cit.

[39] Eric Michael Johnson, "Human Nature and Moral Economy”, Scientific American, September 23, 2013.

[40] Godfrey B. Tangwa, "The Traditional African Perception of a Person: Some Implications for Bioethics" Hastings Center Report 30, $\mathrm{N}^{\circ}$ 5, 2000:39-43. Godfrey B. Tangwa, "Bioethics: An African Perspective" Bioethics 10, $\mathrm{N}^{\circ}$ 3, 1996, pp. 183-200.

[41] Ibid.

[42] Godfrey B. Tangwa, "The Traditional African Perception of a Person", op.cit.

[43] Godfrey B. Tangwa, "Genetic Information: Questions and Worries from an African Background" in Genetic Information: Acquisition, Access, and Control, edited by Alison K. Thompson and Ruth F. Chadwick, New York, Kluwer Academic/Plenum Publishing, 1999, pp.275-281.

[44] Godfrey B. Tangwa, "The HIV/AIDS Pandemic, African Traditional Values and the Search for a Vaccine in Africa" Journal of Medicine and Philosophy, 2002, Volume 27, pp.217-230.

[45] Mogobe B.Ramose, "Towards Emancipative Politics in Modern Africa" in M. Felix Murove (ed.), African Ethics: An Anthology of Comparative and Applied Ethics, Scottsville, University of Kwa-Zulu-Natal Press, pp. 412-426.

[46] (ed.), African Ethics: An Anthology of Comparative and Applied Ethics, Scottsville, University of Kwa-Zulu-Natal Press, 2009, pp.412-426.

[47] James K. Kigongo, op.cit.

[48] Marshall Sahlins, The Western Illusion of Human Nature, Chicago, Prickly Paradigm Press, 2008, p. 1.

[49] Ibid. 
[50] Ibid.

[51] Ibid.

[52] Kwame Gyekye, "Person and Community in African Thought" in P.H. Coetzee and A. P. J. Roux (eds.), op.cit.

[53] Martin H. Prozesky, op.cit.

[54] Thaddeus Metz, "African Moral Theory and Public Governance" in M. Felix Murove (ed.), African Ethics: An Anthology of Comparative and Applied Ethics, Scottsville, University of Kwa-Zulu-Natal Press, 2009, pp.335-356.

[55] Kwame Nkrumah, Consciencism: Philosophy and Ideology for Decolonisation, London, Panaf Books, 1979, p.63.

[56] Godfrey B. Tangwa, "Globalisation or Westernisation? Ethical Concerns in the whole Bio-Business" Bioethics, Volume 13, Number 3/4, 1999.

[57] Mark O. Ikeke, "The Forest in African Traditional Thought and Practice: An Ecophilosophical Discourse" Open Journal of Philosophy, 2013. Vol.3, No.2, 345-350 (http://www.scirp.org/journal/ojpp)

[58] J. A. Ciaffa, "Tradition and Modernity in Postcolonial African Philosophy", Humanitas, Volume XXI, Number 1 and 2, 2008, 121-145.
[59] Chiedozie Okoro, "Philosophy and the Recultivation of African Culture"

(www.unilag.edu.ng/opendoc.php?sno $=3609 \&$ doctype $=$ doc. ..\$, accessed 12/11/2013)

[60] Kwasi Wiredu, Philosophy and an African Culture, Cambridge, Cambridge University Press, 1980, p.21.

[61] Ibid.

[62] Sandra Harding, "Multiculturalism and Postcolonialism: What difference does it Make to Western Scientific Epistemology? Science Studies 1/2001, pp. 45-54.

[63] Kwasi Wiredu, Philosophy and an African Culture, op.cit. p. 43.

[64] Ibid.

[65] Ibid.

[66] Kwame Gyekye, "Philosophy, Culture, and Technology in the Postcolonial" in Emmanuel Chukwudi Eze (ed.), Postcolonial African Philosophy, Cambridge, Blackwell, 1997, p. 42.

[67] Sandra Harding, op.cit. 